$\operatorname{COCOS}(1998-99), 13,01-07$

Printed in Sri Lanka

\title{
EFFECT OF STORAGE TEMPERATURE AND WRAPPING TREATMENTS ON THE KEEPING QUALITY OF TENDER KING COCONUT
}

\author{
C S Ranasinghe, R Wimalasekara, and C Jayasekara
}

Coconut Research Institute, Lunıwila, Sri Lanka

\begin{abstract}
King coconut (Cocos nucifera var. aurantiaca) has a good export market as a natural beverage. However, the quality of the nut has to be maintained for several weeks to meet export market requirements. Therefore, the present study was undertaken to develop techniques to improve the keeping quality of tender king coconuts. Seven-month-old nuts collected from different locations were given wrapping and waxing treatments and stored at low temperature to improve the keeping quality up to four weeks. Invert sugars and total sugars were analyzed. Observations on cosmetic appearance and organoleptic tests were made at initial stage and after storage. The study revealed that the quality of tender king coconuts could be maintained for a period of four weeks when the whole nuts were wrapped with cling film and stored at $14-15^{\circ} \mathrm{C}$, in order to meet export market requirements.
\end{abstract}

\section{INTRODUCTION}

King coconut (Cocos nucifera var. aurantiaca) is a variety known to be endemic to Sri Lanka. The tender nut water is a very popular nutritious natural beverage as it is rich in sugars, vitamins, amino acids and minerals (Ediriweera, 1996; Nanda Kumar, 1995; Dhamodaran et al., 1993; Jayasekara, 1990; Jayasekara and Fernando, 1989; Mohandas, 1983). King coconut is easily and economically grown in almost all the coconut growing lands in Sri Lanka. The price of a king coconut in the local market varies from one to six rupees and is very much higher in the overseas market. The inquiries received from entrepreneurs and foreign visitors to CRI prove that it has high market potential in overseas. King coconuts could be successfully air freighted in good condition to foreign markets within a day or two. But for large export volumes, sea freight would be more economical, but requires about threeweek storage time within the ship. The major problem associated with the export of whole nut is the physico-chemical changes that take place after 
harvest, and during the period of sea freight and transport up to the point of sale. Tender king coconuts cannot be stored for more than one week at ambient temperature due to shrinkage and discoloration of orange coloured outer skin, fall of perianth and fungal attack on the soft perianth region. Therefore, if technology could be developed to improve the shelf life of king coconuts up to four to five weeks, an enormous export potential exists.

The main objective of the present study is to develop a suitable protocol for maintaining the cosmetic appearance of the product and delaying self-decomposition thus prolonging the keeping quality of tender king coconuts.

\section{MATERIALS AND METHODS}

Seven month old king coconuts were collected from different locations, Bandirippuwa Estate, Marawila (intermediate zone) and Walpita (wet zone), throughout the year to minimize seasonal effects and other variations which could alter the composition of nut water. At least three bunches (having a minimum of 18 nuts per bunch) were collected from each location.

Nuts without any physical damage were selected and the outer skin was cleaned using paper tissues. In order to minimize within bunch variations (Fig. 1), the nuts of each bunch were randomly divided into three groups and a minimum of six nuts were assigned to each treatment. The first group of nuts was used to obtain initial data $\left(T_{1}\right)$. A thin layer of paraffin wax was applied on the perianth region of the second group of nuts and these were wrapped with cling film - GLAD WRAP $\left(\mathrm{T}_{2}\right)$. The third group of nuts was wrapped with cling film without applying wax on the perianth region $\left(T_{3}\right)$. The second and third groups of nuts $\left(T_{2}\right.$ and $\left.T_{3}\right)$ were packed with shredded paper in hard board boxes with vents and stored at $14-15^{\circ} \mathrm{C}$ in a cold cabinet (CAMLAB, Cambridge, UK). For biochemical evaluation of the deterioration of nut water and reduction of cosmetic appearance of the tender nut, during storage at room temperature, each bunch collected from Walpita was divided in to four groups. The fourth group of nuts was used as control $\left(\mathrm{T}_{4}\right)$ and stored at room temperature, without imposing any treatment, in the same type of boxes with shredded paper. All the nuts were stored for four weeks and analysis was carried out.

To determine the changes in sugar content during storage, the liquid endosperm of king coconut was analyzed for sugars using high performance liquid chromatography (HPLC) system (Waters, USA) with a Sugar - Pak column. The cosmetic appearance of the nuts was compared using photographs. 

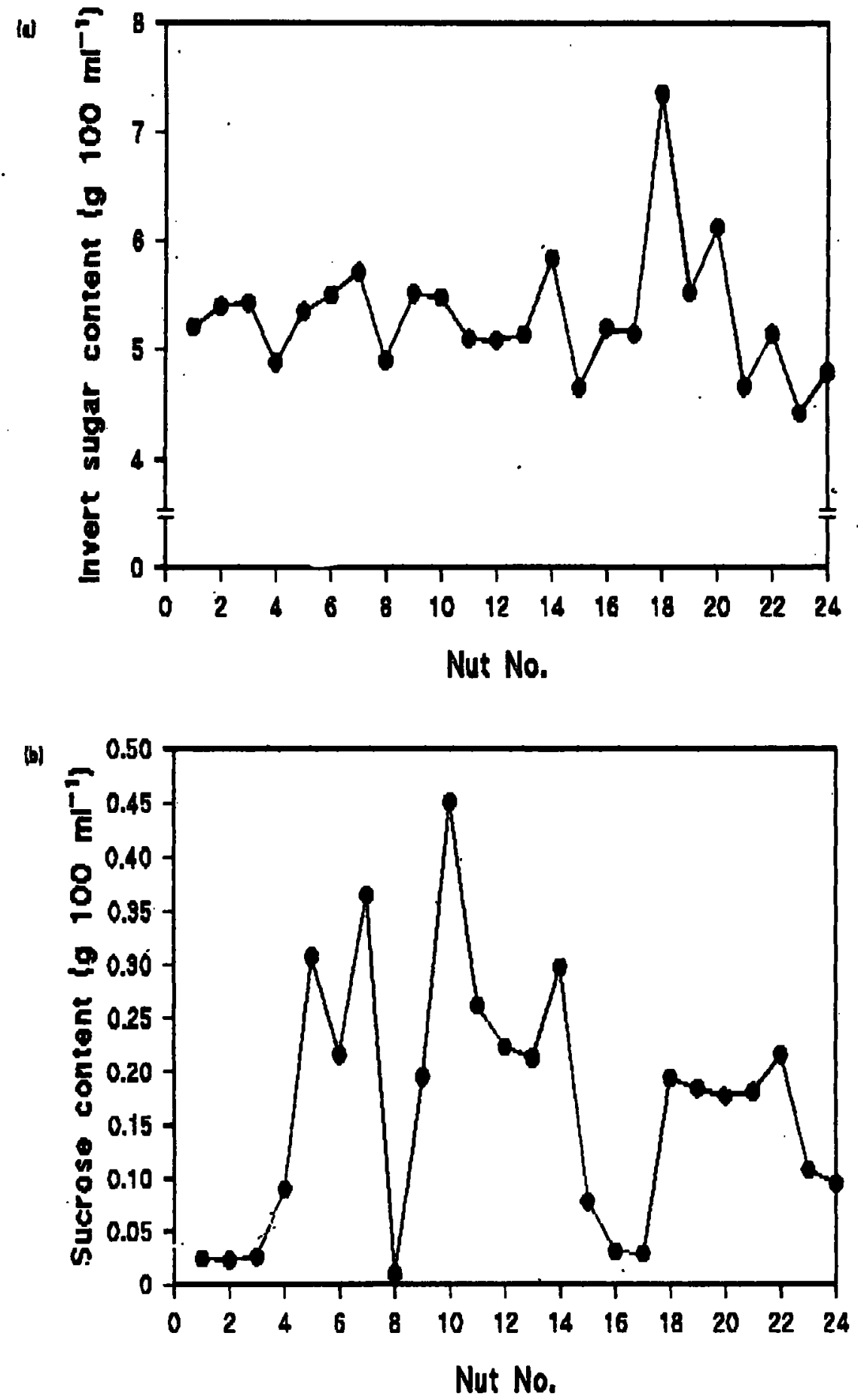

Figure 1: Within bunch variation in (a) invert sugar (glucose and fructose) and (b) sucrose contents in king coconut water Nuts were numbered from proximal end of the bunch. 
The consumer's preference for taste was tested by six independent tasters. The nut water samples were randomly placed and the tasters were asked to taste the nut water and score them as follows.

$\begin{array}{ll}\text { Below average } & 1-3 \\ \text { Satisfactory } & 4-6 \\ \text { Good } & 7-10\end{array}$

The data collection was done on the same day of harvesting and after four weeks of storage.

\section{RESULTS AND DISCUSSION}

The pleasant taste of tender coconut water is attributed mainly to the invert sugars (glucose and fructose) and mineral matter (Chikkasubbanna $e t$ $a l ., 1990)$. When the nut is seven months old, the concentration of invert sugars increases and reaches a maximum and sucrose just begins to be produced in the nut water. The analytical data has proven that the water from nuts at this stage is best suited for drinking (Jayasekara and Fernando, 1989). Further, the volume of water is at its maximum during this stage (Nathanael, 1952). Therefore, seven month old nuts were selected for this study and Table 1 shows the concentration of sugars in the liquid endosperm at initial stage and after four weeks of storage. The data revealed that there was no significant difference in sugar contents among the three treatments, $T_{1}, T_{2}$, and $T_{3}$. The total sugar content was $5-6 \%$ and the invert sugar (glucose and fructose) content was $4-5.5 \%$ in nuts collected from all three locations. Further, as there was no significant difference between the sugar contents of $T_{2}$ and $T_{3}$, waxing the perianth region was not necessary to improve shelf-life of king coconut if the whole nut, including the perianth region, is covered with cling film and stored at $14-15^{\circ} \mathrm{C}$ (Table 1). In the control $\left(\mathrm{T}_{4}\right)$ nuts collected from Walpita the invert sugar (0.5-1\%) and total sugar contents (2$3 \%$ ) were significantly reduced after three weeks compared to initial. After three weeks the perianth region was attacked by fungi and the cosmetic appearance was greatly reduced.

The experiment was repeated with only $T_{1}$ (initial) and $T_{3}$ (cling wrap). and the data are presented in Table 2. The results confirmed that there was no significant difference in sugar contents between initial stage and after four weeks of cold storage, with cling film wrap. 
Table 1: Average sugar content in liquid endosperm of king coconut at initial stage $\left(\mathrm{T}_{1}\right)$, after four weeks of storage at $14-15^{\circ} \mathrm{C}\left(\mathrm{T}_{2}\right.$ and $T_{3}$ ) and after three weeks of storage at room temperature $\left(T_{4}\right)$

\begin{tabular}{lllccc}
\hline Location & Sugar type & \multicolumn{4}{c}{ Sugar content $(\mathrm{g} / 100 \mathrm{ml})$} \\
\cline { 3 - 6 } & & $\begin{array}{c}\text { Initial } \\
\left(\mathrm{T}_{1}\right)\end{array}$ & $\begin{array}{c}\text { With wax } \\
\left(\mathrm{T}_{2}\right)\end{array}$ & $\begin{array}{c}\text { Without wax } \\
\left(\mathrm{T}_{3}\right)\end{array}$ & $\begin{array}{c}\text { Control } \\
\left(\mathrm{T}_{4}\right)\end{array}$ \\
\hline \multirow{2}{*}{ Walpita } & Glucose & 2.86 & 2.13 & 2.04 & 1.00 \\
& Fructose & 2.56 & 1.98 & 2.11 & 0.87 \\
& Sucrose & 0.15 & 0.15 & 0.13 & 0.05 \\
& Total & 5.72 & 5.34 & 5.29 & 2.35 \\
\multirow{5}{*}{ Marawila } & Glucose & 2.56 & 2.14 & 2.49 & 1.30 \\
& Fructose & 2.28 & 1.89 & 1.76 & 0.90 \\
& Sucrose & 0.18 & 0.18 & 0.13 & 0.05 \\
& Total & 5.24 & 4.90 & 5.06 & 2.41 \\
& & & & & \\
BE & Glucose & 2.55 & 2.63 & 2.41 & 1.43 \\
& Fructose & 2.41 & 2.47 & 2.20 & 0.75 \\
& Sucrose & 0.17 & 0.17 & 0.13 & 0.01 \\
& Total & 5.52 & 5.54 & 5.50 & 2.67 \\
\hline
\end{tabular}

BE: Bandirippuwa Estate $\quad n=$ mean of 18 nuts from 3 bunches $(6$ nuts from each bunch)

The photographs taken at the initial stage $\left(T_{1}\right)$ and after four weeks also showed that there was no shrinkage or discoloration of the outer skin, browning of perianth region or perianth fall after four weeks of cold storage, at $14-15^{\circ} \mathrm{C}$, with cling film wrap $\left(\mathrm{T}_{2}\right.$ and $\left.\mathrm{T}_{3}\right)$. In the nuts stored at $14-15^{\circ} \mathrm{C}$, without cling film wrap, shrinkage and discolouration of the outer skin possibly due to dehydration was observed. The observations revealed that the cling film wrap which is a Modified Atmospheric Packing (MAP) system and low temperature storage have preserved the fruit and delayed the self decomposition prolonging the keeping quality of tender king coconuts. Cling film wrap has also prevented the shrinking of the skin by maintaining a suitable humidity level thus giving a good cosmetic appearance to the nut, which is important for the export market. In the nuts stored at room temperature $\left(\mathrm{T}_{4}\right)$, shrinking and browning of the outer skin, perianth fall and fungal attacks on the soft perianth region were observed, and thus the cosmetic appearance was very much below the acceptable level. 
Table 2: Average sugar content in liquid endosperm of king coconut at initial stage $\left(\mathrm{T}_{1}\right)$ and after four weeks of storage at $14-15^{\circ} \mathrm{C}\left(\mathrm{T}_{3}\right)$

\begin{tabular}{llll}
\hline Location & \multicolumn{1}{c}{ Sugar type } & \multicolumn{2}{c}{ Sugar content $(\mathrm{g} / 100 \mathrm{ml})$} \\
& & $\mathrm{T}_{1}$ & $\mathrm{~T}_{3}$ \\
\hline \multirow{3}{*}{ Walpita } & Glucose & 2.56 & 2.05 \\
& Fructose & 2.46 & 2.18 \\
& Sucrose & 0.20 & 0.23 \\
& Total & 5.53 & 5.35 \\
& & & \\
Marawila & Glucose & 2.58 & 2.09 \\
& Fructose & 2.75 & 2.25 \\
& Sucrose & 0.27 & 0.27 \\
& Total & 5.76 & 4.86 \\
& & & \\
Marandawila & Glucose & 2.99 & 2.90 \\
& Fructose & 3.04 & 3.13 \\
& Sucrose & 0.16 & 0.14 \\
& Total & 6.99 & 6.24 \\
\hline
\end{tabular}

$\mathrm{n}=$ mean of 18 nuts from 3 bunches ( 6 nuts from each bunch)

Organoleptic observations indicated that the quality of nut water was not changed in $T_{2}$ and $T_{3}$ when compared to $T_{1}$. The average score for taste for the nuts collected from different locations showed some variation. However, the mean initial $\left(T_{1}\right)$ score was 5 for tender nuts collected from all the locations and the mean final score (after storage) of $T_{2}$ and $T_{3}$ was 6 . It indicated that the quality of nut water was accepted as 'satisfactory' by the consumer both at the initial stage and after storage. The quality of nut water in nuts stored at room temperature $\left(\mathrm{T}_{4}\right)$ was 'below average' and not acceptable to the consumers.

In conclusion, the present study revealed that cling film wrapping and cold storage $\left(14-15^{\circ} \mathrm{C}\right)$ improved the shelf-life of king coconuts up to one month. This low cost post-harvest storage technique could be further tested on king coconuts for longer duration of storage.

\section{ACKNOWLEDGEMENTS}

Our sincere thanks are due to Mrs. W P K K Fernando and Mrs. P S A de Saram for technical assistance and Dr. (Mrs.) L K Weerakoon for carefully reading the manuscript and valuable suggestions. 


\section{REFERENCES}

Chikkasubbanna, V., Jayaprasad, K.V., Subiah, T. and Pooncha, N.M. (1990). Effect of maturity on the chemical composition of tender coconut (Cocos nucifera L. var. Arsikere Tall) water. Indian Coconut Journal 20(12): 1013.

Dhamodaran, S., Ratnambal, M.J., Chempakam, B., Pillai, R.V. and Viraktamath, B.C. (1993). Evaluation in tender nut water in coconut cultivars. In Advances in Coconut Research and Development. Eds. Nair, M.K., Khan, H.H., Gopalasundaram, P. and Bhaskara Rao, E.V.V., Oxford \& IBH publishing Co. Pvt. Ltd., New Delhi: 123-128.

Ediriweera, N.D. (1996). King coconut. CORD XII (2): 43-47.

Jayasekara, C. (1990). High Performance Liquid Chromatographic analysis of carbohydrates in king coconut and ordinary coconut water. Paper presented at the "Workshop on carbohydrates and carbohydrate containing natural products". University of Peradeniya, Peradeniya. 12-16 July 1990.

Jayasekara, C. and Fernando, W.P.K.K. (1989). Studies on sugars and vitamins in coconut water by High Performance Liquid Chromatography (HPLC). Annual Sessions of the Sri Lanka Association for the Advancement of Science. December, 1989.

Mohanadas, S. (1983). Report of the coconut processing research division. In Annual Report of the Coconut Research Institute, Sri Lanka: 122-123.

Nanda Kumar, T.B. (1995). Tender coconut water: nature's finest drink. Indian Coconut Journal XXXII Cocotech Special: 42-45.

Nathanael, W.R.N. (1952). The sugars of coconut water. Ceylon Coconut Quarterly 3, 193-199. 